\title{
Kızım Olmadan Asla: Anne Kız Tüketim Pratikleri ve Narsisizm Kapsamında Değerlendirilmesi
}

\section{Not Without My Daughter: Analysis of Mother-Daughter Consumption Patterns Within the Narcissism Theory}

\section{Şenay Sabah}

Başvuru Tarihi: 08.05.2018

Kabul Tarihi: 28.01.2019

\section{Öz}

Kişiler benliklerini sahiplikleri, evcil hayvanları, geçmişleri gibi faktörler yardımıyla genişletmektedir. Buna göre annelerin de çocuklarını genişletilmiş benliklerinin parçası olarak değerlendirdiklerini söylemek mümkündür. Çalışmada kişilik özelliği olarak narsisist annelerin çocukları için gerçekleştirdikleri tüketim $\mathrm{Ge}$ nişletilmiş Benlik Kuramı kapsamında ele alınmaktadır. Instagramda kızlarının kıyafet tüketimleri ile ilgili paylaşımlarda bulunan ve maksimum çeşitlilik esasına göre belirlenmiş on bir annenin hesaplarının incelenmesi ile veriler toplanmıştır. Toplanan veriler tematik analize tabi tutulmuştur. Çalışma sonucunda annelik-narsisizm ve tüketim ilişkisinin, örneklem kapsamında beş ana eksende ortaya çıktığı görülmüş̧ür. Bunlar, çocuk ile benliğin yansıtılması, gösterişçi tüketim, üstünlük, mükemmel annelik/mükemmel aile ve tüketim aracı olarak çocuk boyutlarıdır.

Anahtar Kelimeler: Narsisizm, Genişletilmiş Benlik, Tüketim, Annelik

\footnotetext{
Abstract

People extend their selves with the help of factors such as personal possessions, their pets, past experiences, and so on. Accordingly, it is possible to say that mothers consider their children as a part of their extended self.
}

In the present study, the consumption of mothers with narcissistic personality for their girls is considered within the scope of Extended Self Theory. Data were collected by examining Instagram accounts of eleven mothers, who share their daughters' clothing consumption. Motherhood-narcissism and consumption relations appeared in five axes: child as a reflection of self, conspicuous consumption, superiority, perfect motherhood/ family, child as a mean for consumption.

Keywords: Narcissism, Extended Self, Consumption, Motherhood

\section{Giriş}

Kimi ünlü giyim markalarının çocukları "küçük yetişkinler" olarak değerlendirmesi ve buna uygun k1yafetler üretmesiyle birlikte, yeni bir akım da görünür hale gelmiştir. Türkiye'de bu akımın ilk temsilcisi olan Koton markası ve çıkardığı "Çocuk Kafası Çocuk Modası" isimli kreasyonu, hem olumlu hem de olumsuz anlamda çok tartışılmıştır. Küçük kızların yetişkinler gibi giydirilmesi kimilerince sevimli ve "stil sahibi” bulunmakla birlikte, çocuk gelişim psikologları başta olmak üzere bir diğer kesim ise çocuklara "küçük yetişkinler" gibi değil çocuk gibi davranılması gerektiğine vurgu yapılmıştır. Bu bağlamda ürünlerin firmalar tarafından sunulmaya başlamasının altyapı-

Şenay Sabah, Ankara Üniversitesi Siyasal Bilgiler Fakültesi, sabah@politics.ankara.edu.tr, ORCID: 0000-0001-5764-6783 
sını oluşturan grup tüketimini, çocuk-ebeveyn tüketiminin dinamiklerinin ve mevcut tüketim toplumu ve onunla yaygınlaştığı öne sürülen narsisizm eğilimlerinin açıklayabileceği öne sürülmektedir (Lambert ve Desmond, 2013).

Bu noktada, benlik kavramı konunun ele alınmasında önemlidir. Sevilen kişiler ve nesnelerin kim olduğumuz üzerinde önemli bir etkisi bulunmaktadır (Ahuvia, 2005). Genişletilmiş Benlik Kuramına (Extended Self Theory) göre benlik; sahiplikler, aile ve arkadaşlar, evcil hayvanlar, geçmiş yaşantı gibi farklı unsurlar1 içerecek şekilde genişlemektedir (Belk,1988, 1990; Walsh, 2007). Buna göre, bireyler tüketim aracilı̆̆ıla kendilerini biricikleştirme, özenilme ve başkalarının dikkatini çekme olanağına kavuşmaktadır. Böylece ürünlerin tüketiminin, özellikle de sembolik ve gösterişçi tüketimin, kişilerin benliklerini oluşturma ve genişletmede önemli bir rol oynadıkları ifade edilmektedir (Mittal, 2006).

Söz konusu tüketim, bireyin sadece bireysel tüketimini değil kendi benliğine dahil ettiği diğer bireylerin/ canlıların tüketimlerini de içermektedir (Stephens ve Hill, 1996; Philips ve Sego, 2011). Buna göre, toplumda tüketim ile birlikte artan narsisizm eğiliminin ortaya çıkma alanlarından biri ebeveyn-çocuk ilişkisi olarak değerlendirilebilir. Kendi benliklerini sahip oldukları birçok "şey" gibi çocuklarının benlikleriyle de genişleten ebeveynler, böylece narsisistik kişiliklerini gerçekleștirecek bir alan oluşturmaktadır. Başka bir ifadeyle, tüketim pratiklerinin yaygınlaşması ve tüketimin sembolik ve gösterişçi yöneliminin artması ile tüketim-narsisizm ilişkisi öne çıkmakta (Gregg, Cisek ve Hart, 2007) ve söz konusu ilişki çocukların tüketimi ile ilişkilendirilmektedir. Bunun için ise yaygınlaşan sosyal medya kullanımı oldukça elverişli bir alan sunmaktadır. Bunun temel nedeni, sosyal medyanın teşhircilik başta olmak üzere narsisizmin boyutlarının ortaya çıkmasını kolaylaştırmasıdır. $\mathrm{Bu}$ çerçevede, annelerin kızları için yaptıkları tüketim davranışlarıyla narsisistik kişiliklerini özellikle sosyal medya aracılığıyla açığa çıkardıkları öne sürülebilir. Bunun yanında, Genişletilmiş Benlik Kuramı (Belk, 1988) çerçevesinde, anneler kızları ve onlar için yaptıkları tüketim ile benliklerini genişletmekte ve sosyal medya bunun gösterilmesi için bir alan veya araç sunmaktadir.
Bu kapsamda; mevcut çalışmada ebeveynlerin, özelinde annelerin narsisistik kişilik özellikleri, benliklerini çocuklarıyla ve onlar için gerçekleştirdikleri tüketim ile genişletmeleri kapsamında ele alınmaktadır. Böylece çalışmanın temel sorunsalı, annelerin kızları için yaptıkları tüketim ve söz konusu tüketimin sosyal medyada görünür kılınması ile kendi benliklerinin ve narsisistik kişilik özelliklerinin hangi eksenlerde genişletildiğinin ele alınmasıdır. Söz konusu amaca uygun olarak, Çalışmada, annelerin üç yaş altı kızları ve onlar için yaptıkları tüketim ile benliklerini genişletmeleri Genişletilmiş Benlik Kuramı çerçevesinde ele alınmaktadır. Böylece, hem kızların hem de onların tüketiminin anneler tarafından kendi benliklerinin aktif bir unsuru olarak değerlendirildiği öne sürülmektedir. Narsisizm alanında birçok çalışma olmakla birlikte, narsisistlerin günlük yaşantısına ve çevrelerindeki insanlarla ilişkilerine dair bilinenler halen çok azdır (Holtzman, Vazire ve Mehl, 2010). Bunun yanında, annelerin benliklerini çocuklarının kıyafet tüketimi yoluyla genişletmesi konusunda halihazırda sınırlı bir yazın bulunmaktadır (McNeill ve Graham, 2014). Söz konusu yazının narsisizm kapsamında ele alınması ise daha da sınırlıdır. Bu çerçevede, çalışmada öncelikle genişletilmiş benlik kuramı ile narsisizmin tüketim ve annelikle ilişkisi ele alınmakta sonra sırasıyla araştırma tasarımına ve sonuçlara yer verilmektedir.

\section{Genişletilmiş Benlik Kuramı}

Genişletilmiş Benlik Kuramı (Extended Self Theory), Belk (1988) tarafından ortaya atılan bir kuram olup kişilerin benliklerini sahip oldukları, aileleri, geçmiş hatıraları, evcil hayvanları gibi faktörleri içerecek biçimde genişlettikleri önermesi üzerine kurulmuştur. Buna göre; sahip olduklarımız yardımıyla, kimliğimizi "hem tanımlamakta hem de kendimize hatırlatmakta olduğumuz" öne sürülmektedir (Belk, 1988). Bu kapsamda tüketiciler, genellikle farkında olmadan kimi zaman ise bilinçli olarak benliklerini tükettikleri ve sahip oldukları nesneler yolu ile oluşturmakta (Mittal, 2006), dahası sahip oldukları ile benliklerini güçlendirmekte ve genişletmektedir (Belk, 1988). Bir diğer ifadeyle "var olmak" ve "sahip olmak" birbirini doğrudan etkileyen unsurlar olarak ele alınabilmektedir (Shankar ve Fitchett, 2002). Fromm'un (1997) 
kişinin kendini "sahip oldukları ve tükettikleri dışında bir hiç" olarak gördügüunü ifade etmesi bu çerçevede anlam kazanmaktadır.

Belk’e (1990) göre kimlik kavramı, nesnel olarak var olan bir olgu değil, kişilerin kendileri hakkındaki sübjektif yargılarına dayanmaktadır. Başka bir ifadeyle, sahip olunan nesnelerden ziyade onlara yüklenen anlam benliğin sınırlarının oluşumunda önem kazanmaktadır. Böylece, kelime anlamı itibariyle üretken bir içeriğe sahip olmayan tüketim, benliğin oluşumunda ve genişlemesinde oynadığ 1 rol dolay1sıyla üretken bir anlam üstlenmektedir. (Goulding ve diğerleri, 2002). İnsanlar, benlikleri için önemli olan ve sahip oldukları nesnelerle bağ kurmakta ve benlikleriyle ilişkili olarak kabul ettikleri nesnelere, ilgisiz nesnelere nazaran yoğun bir bağlllık hissetmektedir. Söz konusu bağlılık ve bu bağlılığın farkındalığı, sadece işlevsel bağ kurulan ve benlikle ilişkili olmayan nesneler ile benliğin genişletilmesinde rol oynayanların birbirinden ayrılması için önemlidir (Belk, 1989). Böylece, sahip olunanlara yüklenen anlam, benlik açısından birincil önem kazanmaktadır. Genişletilmiş benlik kapsamında benliğin temsilcisi olan söz konusu sahiplikler, bireylerin hem düşünce hem de davranışlarını temsil etmekte ve bireylerin "kim olduğunu" tanımlamaya, başkalarına anlatmaya ve hatırlatmaya yardımcı olmaktadır (Belk, 1988).

\section{Narsisizm ve Tüketim}

Karmaşık ve çok boyutlu bir kavram olarak değerlendirilen narsisizm (Panek, Nardis ve Konrath, 2013), en genel biçimiyle kişilerin kendilerini sevme eğilimleri olarak tanımlanmaktadır (Kang ve Park, 2016). Narsisistik kişiliğe sahip bireylerin oldukça yüksek ve gerçekçi olmayan olumlu bir benlik algıları bulunmaktadır (Campbell ve Foster, 2007). Buna göre kavram; kendine odaklı olma, kibirlilik, baskın karakter sahibi olma, sürekli olarak başkalarını etkileme ihtiyacı, üstünlük kurma çabası, teşhircilik gibi boyutlar kapsamında ele alınmaktadır (Cisek, Sedikides, Hart, Godwin, Benson ve Liversedge, 2014; Velov, Gojkovic ve Duric, 2014). Potansiyel tehditlere yönelik kendini koruma çabası ve kişiler arası sıcak ilişkilerin tercih edilmemesi, kavramın diğer bileşenlerindendir (Campbell ve Foster, 2007).
Narsisizmin her bir boyutu farklı tutum ve davranışlar ile kendini göstermektedir. Örneğin, narsisizmin boyutlarından biri olarak kabul edilen teşhircilik, sahip olduklarını başkalarına gösterme isteği gibi günlük davranış ve tutumları içermektedir (Buss ve Chiodo, 1991). Narsisistlerin teşhirci olmalarının bir diğer sonucu, kişilerin kendi fiziksel görünüşlerine yönelik yoğun ilgidir (Vazire, Naumann, Rentfrow ve Gosling, 2008). Narsisistlerin kendi benlikleri merkezli olmaları, iyi görünmek için çok çaba sarf etmeleri ve bedenlerini kamusal olarak gösterme istekleri nedeniyle, narsisizm ile kişinin çekici bir görüntüye sahip olması arasında ilişki olduğu iddia edilebilmektedir. Ancak durumun kişinin daha çekici olup olmaması değil ama kendini öyle görmesi ile ilgili olduğu ifade edilmektedir (Holtzman ve Strube, 2010). Başka bir ifadeyle, narsisistlerin çekiciliklerini abarttıkları öne sürülmektedir (Ong, Ang, Ho, Lim, Goh, Lee ve Chua, 2011). Bir diğer boyut olan başkalarına üstünlük kurma çabasının ise narsisizmin kişinin sahip olduğu değersizlik hissinin bir maskesi olarak değerlendirilmesinden hareketle ortaya çıktığ iddia edilmektedir (Barnett ve Powell, 2016; Horvath ve Morf, 2010).

Çok boyutlu bir kavram olarak ele alınan narsisizm, genel olarak iki biçimde kavramsallaştırılmaktadır. Birinci yaklaşımda narsisizm, var/yok ikiliğinde klinik bir kavram ve kişilik bozukluğu olarak değerlendirilmekle birlikte, ikinci yaklaşıma göre narsisizm farklı derecelerinin olabileceği bir kişilik özelliği olarak kabul edilmektedir (Grijalva vd., 2015). Narsisizmi, ilk yaklaşımdan hareketle, sadece patolojik bir durum olarak ele almanın, konunun basitleştirilmesine yol açtığ ifade edilmektedir (Campbell ve Foster, 2007). Dahası, özellikle tüketimin toplum içerisindeki anlamının ve biçiminin geçirdiği değiş̧ikliklerle birlikte, narsisizmin ikinci yaklaşım çerçevesinde, bir kişilik özelliği olarak ele alınması daha da önemli bir hale gelmiştir (Lambert ve Desmond, 2013). Bu kapsamda, sosyal psikoloji ve kişilik psikolojisi araştırmaları, bahsi geçen iki narsisizmi birbirinden ayrı iki kavram olarak değerlendirmekte (Pincus ve Lukowitsky, 2010) ve ikincisine odaklanmaktadır. Mevcut çalışmada narsisizm bir kişilik özelliği olarak ele alınmaktadır. 
Kişilik özelliği olarak değerlendirilmesinin yanında, narsisizmin kültürelden çok zamana dayalı bir özellik olarak ele alınması gerektiği; başka bir ifadeyle, uygun koşulların varlığına bağlı olduğu öne sürülmektedir (Campbell ve Foster, 2007). Bununla paralel olarak, Genişletilmiş Benlik Kuramına (Belk, 1988) göre, söz konusu durumun kişinin benliğini oluşturan faktörler açısından da geçerli olduğu ifade edilmektedir. Başka bir ifadeyle benliği kuran/oluşturan unsurlar dönemsel olarak değișebilmekte (Belk, 1988) ve bu durum narsisizm kavramının dönemsel özelliği ile uyum göstermektedir.

Narsisizmin zamana bağlı olmasından hareketle, narsisizmi belli kültürlerin değil, belli bir dönemin ürettiği kişilik tipi olarak ele almak, mevcut toplumdaki birçok koşulun narsisistik kişilik özelliklerinin güçlenmesinde rol oynadığını söylemeyi olanaklı kılmaktadır. Bunlardan belki de en önemlisi tüketimdir. Tüketim sisteminin mevcut biçimi, narsisistik kişilik özelliğinin ortaya çıkmasında önemli bir araç olabilmektedir. Tüketim, narsisistlerin aşırı olumlu benlik algısını güçlendirdiği ve narsisist bireylerin bu yolla kendini iyi hissetmesine imkan sağladığı için narsisizm ile ilişkilidir (Harnish ve Bridges, 2015). Nitekim tüketilen ürünler sosyal olarak diğerlerinden daha üst seviyede yer alma ve farklı olma gibi narsisistik kişiliğe uygun mesajları içerebilmektedir (Lee, Gregg ve Park, 2013). Tüketilen nesnelerin tek/biricik olması da onlara yüklenen anlamı artırmaktadır. Özellikle narsisistik bireylerin söz konusu biriciklik durumuna büyük önem verdikleri ifade edilmektedir (Cisek vd., 2014; Lee ve Park, 2011).

Bunun yanında, aşırı/fazla tüketim, lüks ürünlerin tüketimi ve yüksek materyalizm eğilimi de narsisizmin genişlemesi açısından önemli bir zemin oluşturmaktadır (McDonald, Wearing ve Ponting, 2008; Rose, 2007). Bu kapsamda, materyalizm eğilimi yüksek olan bireylerin narsisistik kişilik özelliklerinin de yoğun olduğu ifade edilmektedir (Cisek vd., 2014; Lambert ve Desmond, 2013). Dahası, narsisistik bireyler toplum tarafından onay görme yerine özenilmeyi tercih etmektedir (Lee, Gregg ve Park, 2013). Bu nedenle gösterişçi tüketim kalıplarının yaygınlaşması da narsisizmin yaygınlaşması ile ilişkilidir. Özetle narsisizm, hem materyalizm hem de gösterişçi tüketim gibi dönemin tüketim kalıplarıyla bağlantılıdır (Cisek vd., 2014). Bu çerçevede, söz konusu durumun ortaya çıkmasında mevcut toplum-tüketim ilişkisinin üç özelliği rol oynamaktadır. Bunlar; bireylerin toplum içinde kontrollerinin olmadığına dair inancı ve güçsüzlük hissiyatı; söz konusu kontrolün ve güçsüzlükten kurtulmanın tüketimle gerçekleştirilebileceği algısı ve son olarak da benliğin mevcut toplum içinde bireyler tarafından oluşturulabileceği düşüncesidir (McDonald, Wearing ve Ponting, 2008). Böylece, hem güçsüzlük/kontrolsüzlük hissinden uzaklaşılmasında hem de benliğin kurulmasında ve genişletilmesinde tüketimin önemli rol oynaması ile tüketim kavramı "üretken" işlevler üstlenebilmektedir. Özellikle narsisistik kişilik özelliğine sahip bireyler için söz konusu işlevler öne çıkmaktadır.

Narsisizmin yaygınlaşmasını kolaylaştıran bir diğer faktör, sosyal medya kanallarının kullanımının yaygınlaşmasıdır. Sanal ortam ile gerçek dünyadaki narsisizme ilişkin belirtilerin birbirinden farklı olmadıkları öne sürülmektedir (Dewall, Buffardi, Bonser ve Campbell, 2011). Başka bir ifadeyle, narsisizme ilişkin gerçek dünyadaki belirtiler, sanal dünyada da geçerliliğini korumaktadır. Belirtiler ortak olmakla birlikte, söz konusu belirtilerin sanal dünyada daha az toplumsal baskı ile karşılaştığını ve böylece sanal medya kullanımının narsisizm eğilimini kolaylaştırdığını öne sürmek yanlış olmayacaktır. Bu çerçevede, sosyal medya kullanımının sıklığı ve paylaşılan içeriğin genellikle kişisel fotoğraf olması ile narsisizm eğilimi (özellikle gösterişçilik eğilimi boyutu açısından) arasında pozitif bir korelasyon olduğunu ortaya koyan çalışmalar bulunmaktadır (Panek vd., 2013). Buna göre, narsisistik kişilik özelliklerine sahip bireyler sosyal medya kanallarını çok yoğun olarak kullanmakta, kendi benliklerini bu kanallar ile öne çıkarmaya çalışmaktadır (Lee, Gregg ve Park, 2013).

$\mathrm{Bu}$ çerçevede, narsisistik bireylerin sosyal medyayı kullanmayı yaygin olarak tercih ettikleri ifade edilmektedir (Skues, Williams ve Wise, 2012). Bunun nedenlerinden biri, narsisistlerin sanal dünyada paylaştıkları bilgi ve bilginin ulaştığı izleyici kitlesi gibi faktörler üzerinde çok fazla kontrollerinin olmasıdır (Sheldon ve Bryant, 2016). Bir diğer neden ise sanal dünyanın narsisistlere, gerçek benliklerini abartma konusunda uygun bir platform sunmasidir (Bergman, Fearrington, Davenport ve Bergman, 2011). Dahası sana dünya, narsisistlerin tercih etmediği sıcak ilişkilerin yerine daha gevşek bağlar önerme- 
si dolayısiyla (Bergman, Fearrington, Davenport ve Bergman, 2011), narsisistler için benliklerini oluşturacakları önemli bir alan sunmaktadır. Bunun temel nedeni narsisistik bireylerin olumlu ancak kırılgan bir kişilik yapısına sahip olmaları ve bu nedenle sürekli sosyal onaylanmaya ihtiyaç duymalarıdır (Lee, Gregg ve Park, 2013). Sosyal medya ise onlara bu olanağ 1 sağlamaktadır. Ayrıca, kendini koruma çabası kapsamında, narsisistik kişiliğe sahip bireylerin kendilerine yönelik eleştirilere sert tepki verdikleri ve söz konusu eleştirileri doğrudan reddettikleri öne sürülmektedir (Campbell ve Foster, 2007). Bu çerçevede, narsisist bireylerin kendi benliklerini korumak ad1na sosyal medyada olumsuz bildirimde bulunanları aşağıladıkları, söz konusu yorumları silip yorum yapanları engelledikleri ifade edilmektedir (Horvath ve Morf, 2010). Böylece, hem tüketimin biçim ve anlam değiştirmesi, hem de sosyal medyanın yaygın kullanımı narsisizm eğiliminin artmasını açıklamaktadır.

\section{Narsisizm ve Annelik}

Çok boyutlu bir kavram olarak değerlendirilen narsisizm, kişilerin sahip oldukları toplumsal/bireysel rolleri etkilemektedir. Narsisizm ile ebeveynlik bağlantısı bu anlamda incelenmeye açıktır. Narsisist yetişkinlerin çocuklarıyla kurdukları ilişki değerlendirildiğinde, söz konusu ilişkinin genellikle çocuğa yönelik aşırı ilgi biçiminde gerçekleştiği, başka bir ifadeyle, çok ilgili ebeveynlerin narsisizmlerini bu yolla yeniden ürettikleri ifade edilebilir. Bahsi geçen narsisizmin baskın karakteri, çocuğa yönelik aşırı değer vermedir (Freud, 1957). Ancak söz konusu değer, kişiye bir özne olarak değil kendi benliğini gerçekleştirmenin bir aracı olarak verilmektedir (McDonald, Wearing ve Ponting, 2008). Bu çerçevede, narsisist ebeveynlerin "yansıtmalı özdeșim” kullandıkları, böylece çocuklarını idealize ettiklerini ifade etmek yanlıs olmayacaktır. Yansıtmalı özdeșim kapsamında bireyler, benliklerinin bir parçasını bölüp başka nesnelere/kişilere aktarmakta (yansitmakta) ve söz konusu nesnelerle/kişilerle özdeşim kurmaktadırlar (Crockatt, 2006). Mükemmel olarak değerlendirilme başta olmak üzere birçok özellik karşıdaki nesneye/ kişiye yüklenebilmektedir (Göka, Yüksel ve Göral, 2006). Ebeveynlik kapsamında değerlendirildiğinde, anneler benliklerini çocuklarına yansıttıklarında ve böylece özdeşim kurduklarında, çocuklar anneleri- nin/babalarının benliklerini genişletmenin bir aracı olarak değerlendirilebilmektedir (McNeill ve Graham, 2014).

Ebeveynler, ilgili nesne ve kişileri (mevcut tartışma açısından çocuklarını) benliklerine tekrar dahil etmekte, başka bir ifadeyle benliklerini bu yolla genişletmektedir. Burada, karşıdaki nesneye/kişiye hükmetme ve onu kontrol altına almanın amaçlandığ ifade edilmektedir (Göka vd., 2006). Bunun nedeni narsisistik kişilerin kendi ideal benliklerine ilişkin imaj oluşturmaları ve sistematik olarak benliklerini buna uygun biçimde geliştirmeleridir. Böyle bir durumda, çocuklara ebeveynlerinin gerçekleştir(e) medikleri hayaller yüklenmektedir. Ebeveynlerin çocuklarına yönelik sevgisi, ebeveynlerin narsisizmlerinin ortaya çıkmasını ve çocuğa yönelmesini ifade etmektedir (Freud, 1957). Bu çerçevede, narsisist ebeveynler çocuklarını tüketim de dahil olmak üzere hayatlarının her alanına yaygin olarak dahil etmeye çalışmakta, bu kapsamda benliklerinin onanmasını amaçlamaktadır. Ebeveynlerin bu tip yönelimleri güncel tüketim kültürü içerisinde çocukluğun ticarileştirilmesi şeklinde kendini gösterebilmektedir (Timimi, 2010). Böylece, günümüzde narsisizm-annelik ilişkisinin yaygınlaşmasını kolaylaştıran en önemli konulardan biri, anneliğin tüketimle ilişkilendirilmesi olarak karşımıza çıkmaktadır.

Her ne kadar söz konusu durum hem anne hem de babalar için geçerli olsa da, konunun ele alınmasında annelik öne çıkmaktadır. Babalar genellikle toplumsal olarak çocuk yetiştirme sürecinin dışında bulunmakta, hatta "iyi annelik" kavramının bir göstergesi olarak anneler tarafından bizzat dışarıda tutulmaktadir (Andersen, vd., 2008). Dahası, anneler kizlarının sosyalleşmesinde önemli bir aktördür (Kimura ve Sakashita, 2011) ve çocukla ilgilenen temel özne olarak babalara göre daha önemli bir rol oynamaktadır (Jonason, Lyons ve Bethell, 2014). Böylece, annelerin çocuklarını kendi benliklerinin parçası olarak değerlendirme eğilimlerinin daha yüksek olması beklenebilir. Ayrıca, çelişen kimi çalışmalar bulunmakla birlikte, kadınların fiziksel özellikleri ile daha fazla ilgili oldukları, bu nedenle de kadınlarda narsisistik eğilimlerin daha fazla bulunduğu öne sürülmektedir (Grijalva, Newman, Tay, Donnellan, Harms, Robins ve Yan, 2015). Bu çerçevede, günümüz modern top- 
lumlarında annelik rolleri, narsisizmin ele alınmasında ve benliğin çocuklar yoluyla genişletilmesinde babalık rollerine göre daha fazla olanak sunmaktadır.

Annelik rollerinin, narsisizm ve genişletilmiş benlik kapsamında sunduğu söz konusu olanak, tüketim ile daha da artmaktadır. Günümüzde "iyi annelik" kavramının, "çocuğu için çok fazla ve pahalı tüketim yapma” olarak tanımlandığ 1 ifade edilmektedir (McNeill ve Graham, 2014). Bu kapsamda tüketim, annelik kimliğinin kurulması açısından önemli olmasının yanı sıra (Andersen, Sorensen ve Kjaer, 2008), kişinin söz konusu kimliği olması gerektiği gibi gerçekleştirdiğinin de bir ifadesidir (McNeill ve Graham, 2014). Böylece, günümüzde narsisizm-annelik ilişkisinin yaygınlaşmasını kolaylaştıran en önemli konulardan biri, anneliğin tüketimle ilişkilendirilmesidir. Söz konusu ilişkide, annelerin çocukları için tüketim yaparken de kendileri için gösterdikleri hassasiyetlere (marka, tasarım, fiyat seçimi gibi) sahip oldukları ifade edilmektedir (Gregg, Cisek ve Hart, 2007). Bunun nedeni, çocuğun genişletilmiş benlik içerisinde kabul edilmesidir (Belk, 1988). Bu durum, özellikle küçük çocuklar ve bebekler için daha çok öne çıkmaktadır. Çünkü anneler bebeklerinin tüketimlerinde tamamıla söz sahibidir (Prendergast ve Wong, 2003). Böylece, küçük çocukların giyim tüketimi, annelerin kendi benlikleriyle uyumlu ürünler seçerek benliklerini genişletmeleri açısından önemli bir araç sunmaktadır (Andersen vd., 2008; McNeill ve Graham, 2014). Bu kapsamda, mevcut çalışma açısından, anneler ve kızları çalışmanın araştırma nesnesini oluşturmaktadır. Buna göre, sosyal medyada kızları ile ilgili paylaşım yapan annelerin tüketim davranışları, narsisizm ve genişletilmiş benlik kuramları kapsaminda ele alınmaktadır.

\section{Tasarım ve Yöntem}

Yazında, sosyal medya kullanımının operasyonelleştirilmesi üzerine ve narsisizmle ilişkisine dair kullanışlı ve kabul edilmiş iyi bir teorinin eksikliği ifade edilmektedir (Skues, Williams ve Wise, 2012). Bu nedenle, mevcut çalışmada nitel bir yaklaşım benimsenmiştir. Toplanan veriler tematik analize tabi tutulmuştur. Araştırmada tümevarımcı bir tematik analiz tercih edilmiştir (Braun ve Clarke, 2006). Tümevarımcı tematik analize göre, temalar analiz sırasında ortaya çıkmakta, önceden bir tema seti ile analize başlanmamaktadır (McNeill ve Graham, 2014). Analiz önceden belirli temalara bağlı olarak yapılmadığından, kuramsal açıdan zenginlik ve özgürlük sağlanabilmektedir (McNeill ve Graham, 2014).

Analizin güvenilirliği için Braun ve Clarke (2006, 2012) ile Clarke ve Braun'un (2014) tematik analiz için önerdikleri çerçeve ve adımlar kullanılmıştır. Buna göre, analizin altı temel adımı bulunmaktadır. Bunlardan ilki, verilere aşinalık kazanmaktır. Bu çerçevede, Instagram profillerinden alınan yorumlar ile 44 sayfalık bir doküman oluşturulmuştur. Söz konusu veriler bizzat araştırmacı tarafından hazırlanmış ve oluşturulan doküman analize henüz başlamadan önce birden fazla kere okunmuştur. İkincisi, ilk kodların oluşturulmasıdır. İlk okumadan sonra dokümanın yanına küçük notlar alınarak kodlar oluşturulmaya başlanmıştır. Metnin her başa dönüşünde kodlar güncellenmiş ve son haline getirilmiştir. Üçüncü aşama, temaların araştırılmasıdır. Özellikle kodların oluşturulmaya başlanması aşamasıyla birlikte, temalar üzerinde düşünülmeye başlanmış, kodlar tamamlandıktan sonra söz konusu kodları içerecek temalar araştırılmıştır. Dördüncüsü, potansiyel temaların gözden geçirilmesidir. Temalar oluşturulmaya başlandıktan sonra söz konusu temaların birleştirilmesi, bölünmesi, güncellenmesi, daha önce oluşturulan temalardan vazgeçilmesi veya yeni temalar oluşturulması gibi kararların ardından bu aşama tamamlanmaktadır. Beşinci aşamada, temaların tanımlanması ve isimlendirilmesi bulunmaktadır. Buna göre, bu aşamada temaların birbirini dışlaması ve aynı zamanda her bir temanın içerdiği kodları/alt temaları kapsaması hedeflenmektedir. Temaların içeriklerine uygun isimler verilmiştir. Son aşama olarak ifade edilen araştırma raporunun hazırlanması, aslında gerçek anlamda doğrusal bir aşamayı ifade etmemektedir. Rapor araştırma boyunca yazılmakta, tamamlanması son aşamada gerçekleşmektedir. ${ }^{1}$

1 Çalışma kapsamında ifade edilen analiz süreçleri boyunca, hem temaların başlıkları, hem içerikleri, hem de hangi temaların analiz sonunda raporda sunulacağı değişim göstermiş, analizin olgunluğa eriştiği düşünüldüğünde temalar netleştirilmiştir. Örneğin, araştırmanın başlarında "benliği tanımlayan unsur olarak annelik" teması "taraftar ürünlerinin kullanılması teması ile birleştirilmiş ve "çocuk ile benliğin oluşturulması" teması oluşturulmuştur. "Vefakar/cefakar annelik" teması, tüketim ile ilişkilendirilmesi nedeniyle tüketim ile iyi anne olma teması altında ele alınmıştır. İlk okumalarda "baba-kız ilişkisine yapılan vurgu ve ideal aile" temaları oluşturulmuş ancak daha sonraki okumalarda söz konusu baba- 
Her bir sosyal medya platformunu kullanmanın farklı motivasyonları bulunmasından hareketle, mevcut çalışma açısından Instagram kullanıcıları analize dahil edilmiștir. Bunun nedeni, narsisistlerin fotoğraf paylaşma eğilimlerinin çok yoğun olduğunun ifade edilmesi (Sheldon ve Bryant, 2016) ve Instagramin doğrudan fotoğraf ve video paylaşımına yönelik bir platform olmasidir. Buradan hareketle Instagram'n mevcut çalışmanın ana teması olan tüketim-benlik ilişkisine dair kolaylıkla veri toplanmaya uygun bir platform olduğu düşünülmektedir. Ayrıca, Instagram kullanıcılarının, Facebook gibi platformlardan farklı olarak, çoğunlukla tanımadıkları kişilerden oluşan büyük bir izleyici kitlesine hitap edebilme potansiyeli bulunmaktadır. Söz konusu izleyici kitlesine gösteriş yapabilme olasılığı, narsisistik bireyler açısından oldukça önemlidir (Panek vd., 2013). Başka bir ifadeyle, Instagram Facebook'tan farklı olarak kişilerin sosyal ilişkilerine değil kendi benliklerini ortaya koymalarına odaklanmaktadır (Sheldon ve Bryant, 2016).

$\mathrm{Bu}$ çerçevede, kızlarıyla birlikte özellikle kıyafet tüketimine ilişkin fotoğraflarını yaygın olarak paylaşan, Instagram'da yoğun takip sayılarına sahip, Türkiye'den on bir kadının sosyal medya hesaplarının içerik incelemesi yapılmıștır. Takipçi sayıları dışında dikkat edilen bir diğer konu, kızları sıfır-üç yaş aralığında olan annelerin incelemeye alınmasıdır. Bunun nedeni, söz konusu yaşlarda annelerin çocukların k1yafet tüketimlerinde daha doğrudan bir etkiye sahip olduklarının varsayılmasıdır (Prendergast ve Wong, 2003). Bunun için paylaşılan fotoğraflar ve yapılan yorumlar değerlendirmeye tabi tutulmuştur. Örnekleme dahil edilecek annelerin belirlenmesinde, \#annekız \#anasınınkızı \#annesininkuzusu \#annesiyavrusu gibi anahtar sözcükler ile Instagram'da arama yapılmıştır. Takipçi sayısı on binlerle ifade edilen hesaplar tercih edilmiştir. Araştırmada farklı gelir düzeylerinden, farklı mesleklerden farklı çocuk sayılarına sahip, farklı illerden ve farklı yaşam tarzlarına sahip oldukları düşünülen hesaplar incelenmiş, böylece

\footnotetext{
kız ilişkisinin çocuğun yetiştirilmesini dışarıda tutarak oluşturulduğu ve sadece sevgi/ilgi göstermek olarak tanımlandığı değerlendirilmiş ve "babanın dışarıda tutulması başlığı" oluşturulmuştur. Çalışmanın başında oluşturulan "başka annelere tüketim ile ilgili fikir verme" teması "mükemmel annelik" temasının alt teması olarak düşünülmüştür. Teşhircilik ve hava atma başlıkları ise "gösteriş̧̧i tüketim" teması altında ele alınmıștır.
}

örneklem seçiminde maksimum çeşitlilik ilkesinden yararlanılmıştır. Örneklem grubuna dair diğer bilgiler Ek 1'de yer almaktadır.

İncelenen Instagram hesaplarına dair her bir fotoğraf ve altındaki yorumlar tek tek incelenmiştir. Aynı Instagram hesabının farklı fotoğrafları altında bulunmakla birlikte, analiz sonucunda aynı başlık altında ele alınmasının uygun görüldüğü yorumlar raporlama sırasında bir araya getirilmiş, birbirinden “(...)" ile ayrılmıştır.

Merriam’in (1995) önerdiği çerçevede, yorumların detaylı olarak sunulmasına ve dilbilgisi veya anlatım kurallarına uymak için bile olsa bu yorumlarda değişiklik yapılmamasına dikkat edilmiştir (Lewis, 2009). Böylece, çalışmanın doğrulanabilirliğinin artırılması hedeflenmiştir. Örneklemde yer alan annelerin ve çocuklarının kimlikleri gizlenmiş olup çalışmada her bir anne sırasıyla bir büyük harf ile çocukları ise aynı harfin küçük yazılışı ile gösterilmiştir. Bunun yanında, yorumlarda siklıkla rastlanan marka isimleri de metinden çıkarılmıştır. Instagram yorumlarının fotoğrafsız anlaşılmasının zor olduğunun düşünüldüğü yerlerde, çalışmada fotoğraflara yer verilmediği için, parantez içinde italik karakter ile fotoğrafa ilişkin kısa açıklamalar yapılmıştır. Bunun yanında, söz konusu yorumlarda kalp, bebek, prenses gibi küçük resimler/ figürler ile diğer Instagram kullanıcılarına ulaşmak amacıyla etiketlemeler (tag) yaygın olarak kullanılmaktadır. Söz konusu etiketlere, anlam onlarsız bozulduğu durumlarda metin içerisinde yer verilmiştir. Küçük figürler ise metinden çıkarılmıştır.

Sonuç olarak toplanan verilerin analizi sonunda, metinler arasındaki benzerlik ve farklılıklara dayanarak oluşturulan boyutlar sunulmuştur (Miles ve Huberman, 1984).

\section{Bulgular ve Tartışma}

Çalı̧̧mada annelerin narsisistik özellikleri sadece yoğun sosyal medya kullanımıyla ilişkilendirilmemiştir. Bunun yanında örneklemin narsisizmin birçok boyut ve özelliğini yansıttığı ifade edilebilir. Örneğin, teşhircilik, sürekli başkalarını etkilemeye yönelik ihtiyaç ve kişilerin sahip oldukları nesneleri başka insanlara gösterme isteklerinin narsisizmin günlük davranışla- 
rından olduğu öne sürülmektedir (Buss ve Chiodo, 1991). Çalışmada yer alan anneler için söz konusu boyutlar net olarak görülebilmektedir. Dahası, potansiyel tehditlere yönelik kendini koruma çabasının da (Campbell ve Foster, 2007) narsisizmin boyutu olmasından hareketle, narsisistik kişiliğe sahip bireylerin eleştirilere sert tepki verdikleri ve söz konusu eleştirileri doğrudan reddettikleri öne sürülmektedir (Campbell ve Foster, 2007). Dahası, narsisistlerin kendi benliklerini korumak adına olumsuz eleştiride bulunanları aşağıladıkları ifade edilmektedir (Horvath ve Morf, 2010). Mevcut çalışmada da annelerin olumsuz bildirim ve eleştirileri sildikleri, bu bildirimi yapanları engelledikleri, böyle mesajlar atanları diğer takipçilerine çocuklarının bir fotoğrafı eşliğinde "şikayet ettikleri” görülmektedir. Böylece örneklemde yer alan annelerin, kişilik özelliği olarak narsisizm kavramının ele alınmasında uygun olduğu düşünülmektedir.

$\mathrm{Bu}$ çerçevede, incelenen örneklem kapsamında annelik, narsisizm ve tüketim ilişkisinin beş ana eksende ortaya çıktı̆̆ görülmektedir. Söz konusu boyutlar, çocuk ile benliğin yansıtılması, gösterişçi tüketim, üstünlük, mükemmel annelik/mükemmel aile ve tüketimin aracı olarak çocuktur.

\section{Çocuğum ile Kendimi Yansıtırım}

Narsisistik annelerin çocukları için tüketim yaparken kendileri için de seçebilecekleri ürünleri, markaları, kumaşları ve renkleri tercih ettikleri ifade edilmektedir (McNeill ve Graham, 2014). Buna uygun olarak mevcut araştırma kapsamında ele alınan annelerin kıyafet tüketiminde, çocukları ile "anne-kız kombini" adını verdikleri bir tüketim biçimi yaygın olarak görülmektedir.

"Illk anne- kız kombini girişimim başarıyla sonuçlanmıştır darısı biraz daha zayıflayınca inşallah (...) $\mathrm{Na}$ sll da annesine benziyor yaaa «dediğinizi duyar gibiyim (...) Annesine çekmiş gülünce tüm dişlerini görebilirsiniz (...) a ile bayram kombini yaptık anne-kız" (A)

"Her gün gözümün önünde büyürken ona hayran kalmamak elde değil... Kendimle gurur duyuyorum evet onu ben yaptim hahah (...) Annesi yavrusu Balkan kızları (...) Anasina bak kizinı al desinler diye hep bu cabalar. Kusura bakmayın kızlar ikinizden de güzel ben olacağım en güzel nisan kızı benim çünkü ben
D’nin kızıyım (...) Bizde heyecan biter mi hiç D gelinin kızı olmak kolay değil." (D)

Buna göre anne ve kızı, aynı kıyafetin kendilerine uyan boyutlarını giymektedir. Böylece, anneler çocukları için kendi benlikleriyle uyumlu, kendilerinin de giyebilecekleri ya da bizzat giydikleri ürünleri seçerek benliklerini genişletebilmektedir (Andersen vd., 2008; McNeill ve Graham, 2014). Mevcut çalışmada henüz bir buçuk aylık çocuğu olan J dışında tüm annelerin en az bir kere "anne-kız kombini" yaptıkları görülmektedir.

"e’nin bu Yaz'a vedası olarak burada dursun o zmn \#yazbitti Kapanışı. anne\&kız pareoları ile yaptık Annişkom böyle kombin yapmayı nerden öğrendi. Kombin bizim işimiz. Çünkü \#ikoncane (...) annedkız minnoşluğu bu olsa gerek. Hiç mütevazii olamayacağız vallah" $(E)$

"Yok efendim o f'nin coolluğu bizle alakası yok. Anne kız takım baskılı T-shirt" (F)

"Selam kızlar annemin kızıyım (...) İlk kez anne kız bişi giyiyorum. ama çok minnoş değil mi ismimizin baş harflerinin yazılı olduğu tişörtlerimiz (...) SES veriyorum.Korkmaaa.....Müzik öğretmeni annenin müzik öğretmeni kızı. yönetiyor yaHU.” (G)

"Güzellik gecicidir, anneden kizina geçer. iste buda kaniti (...) Anne kiz kotlari giyip bir örnek olduk. haydi biz gezmeye (...) Çok mu güzeliz acaba, anali kizli Allahiimm nasil bişi doğurmuşum bennn" $(H)$

Anne-kız kombinleri ile annelerin doğrudan kendilerinin de giyebilecekleri ürün ve markaları çocukları için de tercih ettiklerini söylemek mümkündür. Böylece, annenin benliğinin bir uzantısı olarak değerlendirilen çocuklar için yapılan tüketimin de aynı işlevi gördüğü söylenebilmektedir.

"Benim minik yansımalarım. (...) Kiz evladı olmalı her kadının günden güne kendine daha çok benzeyen (...) Anne-kiz kombinimiz Renkleriyle bizi tamamen beni anlatan hamis kemerim ve tacim(...) Askmisin kizim sen? Büyün huzur mutlulugu barindiyorsun sanki kokunda tabiki biz yine anne-kizliydik dün gzl eteklerimizle (...)Bafrayada Anne-kiz modasi getirdik" (I)

"Pişti olmak bizim işimiz (kızıyla aynı kıyafet) (...) Bence biz iyi bir takımız (aynı kıyafet) (...) Aaa ne tatl 
ana kız (...) İyiler beyaz giyer (tüm aile ayn giyinmiş) (...) Bazı kızlara yeşil çok yakışıyor diyolar (ikisi de yeşil) (...)biz yine ana kız kombini (...) Bazı kızlar çok anasinin kizı (...)" $(K)$

Narsisist bireyler açısından ürünün tekliği, biricikliği ürünün anlamını artırmakla birlikte (Cisek vd., 2014; Lee ve Park, 2011), anne-kız ortak kıyafet giyimi, annelerin kızlarını kendilerinin genişletilmiş benliklerinin bir parçası olarak görmeleri nedeniyle, biricikliği bozmamaktadır. Çocuk ile kendi benliğini yansıtmanın, başka bir ifadeyle çocuğun genişletilmiş benliğin bir parçası olarak ele alındığını ifade eden bir diğer örnek, çocuğun genellikle ailecek tutulan futbol tak1mının ürünleri ile fotoğrafının paylaşılmasıdır. Çünkü kişilerin tuttukları takımlar, söz konusu takıma olan aidiyet ve bağlllık duyguları ile bunu ifade etmek üzere tüketilen takım ürünleri, genişletilmiş benlik kuramı çerçevesinde, benliğin bir unsuru olarak ele alınmaktadır (Madrigal, 2000). Buna göre, incelenen annelerin çoğunluğu $(\mathrm{C}, \mathrm{D}, \mathrm{E}, \mathrm{H}, \mathrm{I}, \mathrm{J}, \mathrm{K})$, çocuklarının tuttukları takımın ürünleri ile fotoğraflarını paylaşmıştır.

"d 1 yaşında 2.sampiyonlugunu gördü hemde 3.yildizi takmak nasip oldu. Teşekkürler Besiktasim. Dişi Kartal yetişiyor (forma ile)" (D)

“\#kocaelisporlu babaya ve takipçilere özel yeşile riyah kombin” (E)

"Babam galatasarayli olduğu için bende otomatik olarak galatasarayli oluyorum galba" (sarı kırmızı saç bandi) $(H)$

"Herkesin iyi ki dedigi birseyler vardır..Beniimm ilk aklıma gelen iyi kim CANN \#fenerbahçe\#sarılacivert \#aşk (hepsinde Fenerbahçe tişörtü” (I)

Bunun yanında, incelenen bireylerin "ben" kelimesini, çocuklarından bahsederken ise "biz" kelimesini çok yaygın kullandıkları görülmektedir. Ayrıca çocuğunu tanımlarken "annesine benzerlik" vurgusu yapılmakta ve söz konusu benzerlik annelerin yaygın kullanımıyla "kokoş"luk, genelleştirmek gerekirse kıyafet tüketimi üzerinden kurulmaktadır. Kişilerin ilgiyi kendine çekme çabasını ifade eden söz konusu hareket, geçmiş narsisizm yazınıyla da uyumludur (Dewall, Buffardi, Bonser ve Campbell, 2011; Lee, Gregg ve Park, 2013).

\section{Gösterişçi Tüketim}

Çalışma kapsamında ortaya çıkan ikinci boyut "gösterişçi tüketim"dir. Küçük çocukların toplumda çok görünür ve ilgi çekici olması nedeniyle, genişletilmiş benliğin bir parçası olarak kabul edilmesi, onlar için yapılan tüketimin ise gösterişçi tüketim kapsamında değerlendirilmelerinin mümkün olduğu ifade edilmektedir (McNeill ve Graham, 2014). Çünkü lüks markalar ve pahalı ürünler giyen bir çocuk ebeveynleri açısından statü sembolüdür (Andersen vd., 2008; Prendergast ve Wong, 2003).

"Doğuştan kokoşlar var aramızda (...) Feyşın blogger olur mu dersiniz ilerde a'dan. Uçuşan paçalarını yicem fistık (İspanyol paça pantolon) (...)ànın ateşi sanırım diş ateşi üst dişler biraz zorladi alt dişleri hissettirmemişti bukadar. a’nın kokoş takımı (leopar desenli) (...) Püsküllü bot modasını es geçermiyiz hiç (...) Saç bandı kadar tiryakisi olabilirim bu kokoş berelerin (leoparpayetli) (...) Güne kokoş başlayanlar günaydın. kokoşluktan yıkılan makosenlerimiz" (A)

"Haval gözlüklerimiz ve plaj ayakkabılarımız (...) Şu kız deri taytları etekleri giymeye başladıktan sonra anladım ki büyüdü (...) x hadi sapkani tak elbiseni giy seni tenis kortunda bekliyorum (tenis kiyafeti ile) (...) Heyy kızlar biz Uludağa çıkmaya haziriz. Kürkümüzü botlarimizi giydik. (...)4.5 aylik olabiliriz ama tarz olmayı sizden öğrenecek değiliz hihii” (D)

Lüks ürünlerin veya kürk/deri gibi lüks ve gösteriş sembolü olarak kabul edilen ürünlerin çocuklar tarafından sergilenmesi, anneleri açısından bir statü sembolü olarak değerlendirilmektedir (Andersen vd., 2008; Prendergast ve Wong, 2003). Böylece, çocuklar1 ile benliklerini genişleten anneler, bu vesileyle narsisist eğilimlerini de güçlendirmektedir (McDonald, Wearing ve Ponting, 2008; Rose, 2007). Buna göre, incelenen annelerin neredeyse tamamı (F hariç) tükettikleri lüks markaları fotoğrafların altında belirtmektedir.

"Bir \#ikoncane kolay yetişmiyor cınıım. (...) Tam feyşnın blogger olcam gülesim geliveriyor (...) Ne kadarda güneş gözlüklü ponçik bir kız (...) Leopar giydim diye mutlu sanıyollaă̆ (...) altın gününe gidecek gibi görünsemde annemle alş̧verişe gidiyorduk hepsi bu. Çünkü \#ikoncane olmak bunu gerektirir (...) Çünküünümmm bazen boyfriend stayla takılmayı seviyoreeğ (...)findık kurdumun bugün ki leopar kombini” (E) 
"Serseri serbest stili (...) Leoparlı pijama takımı (...) Taçlarimiz ve ispanyol pantolonumuz cok sevildi (...) Farkimiz tarzimiz (...) bu tarz bizim (...) leoparl şapkalar (...) gebeyken yaptık o kadar şu tütüleri giyemeden küçülselermiydi yanı (...) sabah sabah pek şıkız değil mi ?" (F)

F ise düşük fiyat öneren markaları tükettiğini belirtmekle birlikte, lüks sembolü olan markalar ile değilse bile (leopar/prenses tacı/İspanyol paça gibi) ürün grupları ile kızlarının fotoğraflarını paylaşmaktadır. Çünkü sadece lüks markalar değil bunun yanında lüks ve gösteriş sembolü kabul edilen kimi ürünlerin (kürkler, deri, leopar desenli veya payetli kıyafetler, güneş gözlükleri, çocuklar için otomobiller gibi) tüketimi de yine gösterişçi tüketim kapsamında ele alınabilmektedir.

"Yoksa sizin hala tütünüz Yok mu (...) Dün yine sirt dekoltemi merak edenler olmuş (...) Annecim bi dak$k a$ gözlüklerini verir misin takayım da öyle çek pozu (...) Kıslar gün geçmiyor ki tasarım bir kıyafet giymeyeyim (...) Gözlüklerim şekil önümden çekil albümü (...)Guccigirl" (G)

"Kokoslukta sinir tanimiyo kendileri (...) Esofmanimiz bile leoparli (...) Tütü giydim prenses oldum diye bu havalar kime acaba (...)Leoparli kokoş bütün yayladayi kendine hayran birakti" $(H)$

\section{"Bazı kızlar çok kokoş (16 Ekim)" (J)}

"Bazı kızlar șıkliğından asla ödün vermezler. (...) Flamingosuz $k$ ve anası olamazdı (...) Kendini çekimlerde falan sandı bence (güneş gözlüğü, bikini, kafasında bant) (...) Yine bigün ball lokma tatlısiyım.. (kürk mont) (...) Baleye gidiyorum. Nasıl olmuşum kızlar (tütü)" (K)

İncelenen annelerin neredeyse tamamı (B hariç), lüks ve pahalı ürünler ile gösteriş sembolü kabul edilen ürünleri Instagram fotoğraflarında yaygın olarak kullanmaktadır. Bunun yanında sahip olunan ürünlerin tek ve biricik olması hem gösterişçi tüketim hem de narsisizm açısından önemlidir. Çalışmada incelenen annelerin neredeyse tamamı (F ve J hariç), hem kızları hem de kızları ile birlikte giymek üzere kendileri için tasarım kıyafetleri tercih etmektedir.

\section{Üstünlük}

Çalışmanın sonuçlarında ortaya çıkan üçüncü eksen “üstünlük”tür. Narsisistik annelerin çocuklarını diğer bütün çocuklardan üstün gördükleri öne sürülmektedir (Lambert ve Desmond, 2013). İncelenen bireylerin tamamının çocuklarını diğer çocuklardan üstün olarak gördükleri izlenimi oluşturacak kavramları (prenses, sultan, matmazel, miss world gibi) sıklıkla kullandıkları görülmektedir. Söz konusu üstünlük açısından tüketim önem arz etmektedir.

"Ablan star bebeyimmm. (...) My little princess. Tütü tayt (...) Sultan oturuşuna bakar misinız (...) Miss Turkey 2016 Bebek Güzeli. Kiyafetimiz (taç) (...) Vintage Princess. Muhteşem takım"(A)

"Bir mankenmis gibi çek anne (...) Minik prensesim ile güne başlayınca belki gün enerjik devam eder diye de hem kendim hem sizin için buraya bir adet ball lokum birakıyorum" (C)

"Moda ikonu kim kaldı ki şurda bi Şeyma bi ben o da evlendiğine göre sahalar bana kald cınımmm (...) Beyaz atl prensini bekliyor. (...)Matmazel d huzurlarınızda. Mükemmel elbisemiz sayenizde kendimizi İngiltere kraliyetinin düşesi gibi hissettik (...) d bugün 3 aylik oldu. O tam bir prenses." (D)

Narsisimin bir boyutu olan kendini üstün görme ile tüketim kavramının ilişkisi bu anlamda çalışmanın oldukça özgün bir sonucunu oluşturmaktadır. Başka bir ifadeyle, örneğin "prenses" derken çocuğun kafasında taç bulunmakta, "miss world" fotoğraflarında kızlar çok şık elbiselerle poz verdirilmektedir.

"Plajın en cool kızı olur kendisi (...) Miss World 2017 tac $\iota \mathrm{m} ı$ taktıklarında ben (...). Piyemses tacı" (E)

"Ben şey değil mi ya. Asil Piremses pozu (...) Prenses tişörtü (...) Peki ya bu asi piremses?" (F)

"My african queen. (...) sadece prensesler giyebilir" (G)

"Prensessin diye mutlu saniyorlar (ağlayan fotoğraf) (...) Bir prenses görüyorum sanki.” (H)

"Minik mankenlerim benim (trençkotlar, şapkalar)" (I) 
"İște şimdi gerçek bir pilemses (...)Buraların karpuz güzeli kim tartışmayalım istersen (karpuzlu elbise) (...) ohhh biraz da şöyle güneşleniyim piremsesler gibi" (K)

Burada mevcut çalışmanın araştırma sorusu ile ilgili en çok dikkat çeken konu, söz konusu üstünlük vurgusunun yine tüketilenler aracılı̆̆ıyla kurulmasıdır. Söz konusu vurgu B ve J dışında tüm annelerin Instagram paylaşımlarında görülebilmektedir. Böylece, diğer boyutlarda olduğu gibi üstünlük boyutunun ortaya çıkışında da tüketim ilgili bir faktör olarak görünmektedir.

\section{Mükemmel Annelik, Mükemmel Aile}

Mükemmel annelik konusunun en önemli karşıllğ̆1nın, "çocuğun her şeyden önce gelmesi" olduğu ifade edilmektedir (McNeill ve Graham, 2014). İncelenen Instagram profillerinde söz konusu mükemmellik algısının tüketim ile birlikte değerlendirilebileceği görülmektedir. Başka bir ifadeyle, anneler ne kadar mükemmel bir anne/eş olduklarını çocukları için tükettikleri vesilesiyle görünür kılmaktadır.

"Daddy's sweetheart (tişört) Çünkü o babasının biricik kızı (...) Rabbim babanı başımızdan ayırmasın diye dua etmemin en büyük sebebi bu gülüşlerin (leopar desenli kiyafet ve bant)" (A)

"Kendine diye alışverişe çıkı minigine alışveriş yapıp geri donmekmis annelik" (C)

"Eğer bir Anne iseniz çantanızda parfüm ayna rimel değilde bez islak mendil oyuncak ve termos taşırsıniz. O yüzden çok fonksiyonlu bölmeli é tabi birde kokos ruhunuzu yansitan bir sirt cantasi istersiniz. (...) Mutlu aile $=$ Mutlu bebek derler. çok şükür ki kizimizi böyle bir ailede büyütüyoruz. Guzel kombinimiz tam bahar havasına yakıştı." (D)

Buna göre, çocuklarına güzel kıyafetler alarak annelerin çocuklarına iyi baktıklarını düşündükleri ve böylece kendilerini "iyi anne" olarak gördükleri ifade edilmektedir (Andersen vd., 2008).

"\#babakiz aşkı babaßkız kombin (...) hep anneঊkız olmaz diyollağğ. biraz da baba\&kiz olsun o zmn \#batman aşkına" (E)
"Ask diye yazilir EVLAT diye okunur. Takimlar ve ayakkabılar (...) Okadar \#subliminalmesajicerir \#supermom" (hepsinde aynı superman tişörtü) (F)

"İy gecelerrr" (I love daddy şapkası ve daddy's princess zıbını) (K)

Bunun yanında, çalışmada incelenen hesaplarda kadınların, aldıkları tüm ürünleri nereden aldıklarını da belirttikleri görülmektedir². Başka bir ifadeyle, "mükemmel" anneliğin getirdiği ideal annelik rolü kapsamında, başka annelere "tüketim" konusunda fikir verilmektedir. İncelenen profillerin tamamında söz konusu vurgu görülmekle birlikte, doğrudan ve açık olarak altı annenin (A, C, D, E, F, K) bu durumu ifade ettiği söylenebilir. Buna göre, örnek anne-eş olmanın tüketim konusunda da onları örnek kıldığı ifade edilebilir. Ayrıca, "mükemmel annelik" kavramına uygun olarak babaların çocukla ilgili paylaşımların genellikle dışında bulundukları ya da anneler tarafından bizzat dışarıda tutuldukları öne sürülmektedir (Andersen, vd., 2008). Çalışma sonucunda da, baba figürü, incelenen tüm anneler için fotoğraflarda kimi zaman görünmekle birlikte, çocuk bakımı ile ilgili bir sorumluluklarının bahsi geçmemektedir. Babalar çogunlukla sadece "annelerin ve kızların aşık oldukları adam” olarak resmedilmektedir.

\section{Tüketim Aracı Olarak Çocuk}

Araştırma kapsamında annelerin, çocukları olduktan sonra kendileri için tüketimi eskisi kadar sık yapmadıkları, artık tüketimin büyük oranda çocuk ekseninde gerçekleştiği ifade edilmektedir. Buna göre, çocuk sonrası kendileri için eskisi kadar alışveriş yapmadıklarını ifade eden anneler, çocuklarını kendi zevklerine uygun birer yetişkin gibi giydirerek söz konusu eksikliği gidermeye çalışmaktadır. Böyle olmadığ 1 durumlarda bile, tüketimin genellikle çocukla bir ilgisi kurulmaktadır. Böylece çocuk, annenin tüketiminin bir aracı haline gelmektedir (Andersen vd., 2008). Örneğin, alınan çantalar çocuğun eşyalarını kolaylıkla taşıma özelliğine göre tercih edilmekte, kıyafetler ise çocukla birörnek olarak seçilmektedir.

"Elbiselerin hepsiyle çekim yaptığımıza göre artık dekor olarak odamızı süsleyebilirler. İlerde kombinlerini kendi seçmesi için boyuna göre yaptırdım. Kıyafet askı-

2 Çalışmada markalar metinden çıkarıldığı için bu duruma ilişkin kanıtlar metin içerisinde sunulamamıştır. 
l̆ğımız (...) Buarada elbiseyi satmayı düşünmüyorum arkadaşlar çok soran oluyor. Dolabın kapağını açınca bana mutluluk veren bişeyi nasıl satabilirim. (...) Neyse ki aldiğım tüm yazliklar elimde patlamadan geldi yaz. Felaket bi sicak var bugün cibıl cıbıl a." (A)

"Serseri style kızımla kahvaltıya gittikten sonra babaannemizin elini öptük birazdan da anneannemizi görüntülü arıycaz." (B)

"Kızına alısveriş yapan anne mutluluğu." (C)

"Tüm çocuklarımızın ulusal egemenlik ve çocuk bayramı kutlu olsun. Bugüne özel bu kontes kombinimiz. (...) İstanbulıa penguenler gelmiş öyleyse penguenli tulumuтиzu giyip onlari görmeye gidelim (...) Yeni yil akşamı paylasilamayan bir Noel anne fotoğrafı gelsin öyleyse. Noel Anne d." (D)

Benzer şekilde, annelerin çocuklarının tüketiminde kendi tüketimlerindeki hassasiyetleri (marka, tasarım, fiyat seçimi gibi) bire bir gösterdikleri ifade edilmektedir (Gregg, Cisek ve Hart, 2007). Bu çerçevede, annelerin çocuklarını yetişkin gibi giydirerek ve kendi giyebilecekleri/giydikleri kıyafetleri çocukları için de tercih ederek çocuklarını kendi tüketimleri için bir aracı olarak değerlendirdikleri öne sürülmektedir (Andersen vd., 2008). Bu kapsamda, örneklemde yer alan annelerden neredeyse tamamında (J hariç), çocukların tüketim aracı olarak değerlendirildiği izlenimi edinilmektedir.

"Çünkü bugün 10 Kasım! yakasında siyah kurdelesi yok ama siyah saç bandımız Atamız için (...) şöyle bir 90^lar partisi daveti filan olursa hazırlandik akıp gitçezde davet yok"(E)

"kıyafetimi kuzenimin 6 ay kınası için yaptırdım kıslarr Mevlüt style (...) Siz sormadan söyleyeyim beni annem giydiriyor tüm parasını bana yatırıyor" $(G)$

"Kuzum hasta oldu teyzoşlari, dua edinde çabucak iyileşsin. kirmizi kokoş şapkamiz hasta yüzümüze renk kati." $(\mathrm{H})$

“Güclü kızlarım benim (süperman tişörtü ile) (I)

"Hamama giren terler \#hamamdaolsaşıkliğımızdanödünvermeyz" (K)
Çocukların anneleri tarafından tüketimin bir arac1 olarak görülmesinin bir diğer biçimi, çocukların “oyuncak bebek"lere benzetilmesidir. Buna göre, tıpkı oyuncak bebeğin giydirilmesi gibi, çocuklar da giydirilmektedir. Anne çocuğunu kendi benliğini genişletme "nesnesi" olarak değerlendirdiğinden (McNeill ve Graham, 2014) bir özne olarak benliğinin dışında konumlandırmamaktadır. Böylece bir "nesne" olarak çocuk, annenin kendi narsisistik eğiliminin sergilendiği bir alan olarak değerlendirilmektedir (McDonald, Wearing ve Ponting, 2008). İncelenen annelerin önemli bir kısmında (A, E, G, H, J, K) söz konusu benzetme görülebilmektedir. ${ }^{3}$

“a’ya en son nezaman etek giydirdim hiiiiç hatırlamıyorum. Ama özlemişim şu fistı̆̆ barbie bebek gibi görmeyi (...) Fiyonk totolu bir adet oyuncak bebek. (...) Oyuncak bebekmiş bi zamanlar (eski bir fotoğraf ile) (...) Küçüklügü̈mde et bebeğim vardı yanımdan ayırmadığım a'yı ona çok benzetiyorum" (A)

"ya oyuncak mısın sen çocuk. severken nefesim kesiliyor. çok beğenilen bandanamız" (E)

"Biri biblo mu dedi. Yoksa sizin halâ tütünüz yok mu" (G)

"Hangisi oyuncak bulun bakalimmm, oyuncak bebeğim benimmm" $(\mathrm{H})$

"Oyuncak bebek gibi” (J)

"Oyuncakların hepsini sepete doldurduk. (k de sepette)" (K)

Yukarıda ifade edilen biçimiyle, annelerin benliklerini genişletmenin bir aracı olarak değerlendirilen çocuk, aynı zamanda annelerin narsisistik eğilimlerini tüketim ile gerçekleştirebilecekleri bir araç olarak da ele alınmaktadır.

3 F’nin de kızları ile ilgili oyuncak bebeğe benzettiği ifadeler bulunmakla birlikte, çocukların prematüre doğmuş olmaları ve bu nedenle yaşıtlarına göre daha küçük görünmeleri sebebiyle de söz konusu ifadenin söylenmiş olabileceği düşünülmektedir. Bu nedenle, yukarıda yer alan benzetmede F’nin ifadelerine yer verilmemiștir. 


\section{Sonuç}

Çalışma, narsisizm, tüketim ve genişletilmiş benlik yazınını annelerin kızları için tüketimi kapsamında bir araya getirmesi ve bu alana ilişkin sınırlı yazın nedeniyle önemli sonuçlar sunmaktadır. Araştırma sonucunda beş ana eksen ortaya çıkmıştır. Bunlar, çocuk ile benliğin yansıtılması, gösterişçi tüketim, üstünlük, mükemmel annelik/mükemmel aile ve tüketimin aracı olarak çocuk boyutlarıdır. Çalışma narsisizm kavramının "kişilik özelliği" olarak yorumlanması ile sınırlıdır. Mevcut yazında ihtiyaç duyulduğu ifade edilen (Holtzman, Vazire ve Mehl, 2010) narsisist bireylerin günlük yaşantılarında gerçekleștirdikleri davranışların ve çevrelerindeki bireylerle ilişkilerinin yorumlanmasına dayanmaktadır. Bu çerçevede kişilik özelliği olarak narsisizm ve kimlik unsuru olarak kabul edilen annelik bir arada ele alınmıştır.

Çalışma iki temel teorik argümanı hem desteklemekte hem de genişletmektedir: (1) Bireyler benliklerini kendileri için önemli olan şeyler ve kişilerle genişletmektedir (Belk, 1988). (2) Tüketim, hem narsisizm eğiliminin ortaya konulmasında (Cisek vd., 2014; McDonald, Wearing ve Ponting, 2008; Rose, 2007) hem de benliğin genişletilmesinde aktif rol oynamaktadır (Belk, 1988, 1989; Goulding ve diğerleri, 2002). Belk (1988)'in Genişletilmiş Benlik Kuramı kapsamında, annelerin hem kızlarını hem de kızlarının tüketimlerini benliklerinin genişletilmesinde kullandıkları önermesi desteklenmiştir. Bunun yanında kurama ek olarak narsisizm kavramının da söz konusu genişletmede bir aracı rolü üstlenebileceği önerilmektedir. Başka bir ifadeyle, narsisizm, "yansitmalı özdeşim” kavramının bağlamında, anneler için benliğin çocuk ve onun tüketimi ile genişletilmesine olanak sağlamaktadır.

İkinci olarak, tüketimin, özelinde de lüks (McDonald, Wearing ve Ponting, 2008; Rose, 2007) ve gösterişçi tüketimin (Cisek vd., 2014), narsisim ile ilişkili olabileceği önermesi çalışma kapsamında desteklenmektedir. Bununla beraber, mevcut yazına ek olarak, söz konusu durumun sadece bireyin kendi tüketimi ile s1nırlı olmadığı, kendisi için önemli olan “diğerleri”nin tüketimlerinin de bu kapsamda değerlendirilebileceği çalışma sonuçlarınca önerilmektedir. Çalışmada Genişletilmiş Benlik Kuramından yararlanılması söz konusu önermeye olanak sağlamaktadır. Tüketim, mevcut yazına uygun olarak aynı zamanda benliğin genişletilmesinin de bir aracı olarak değerlendirilmiştir (Goulding ve diğerleri, 2002). Böylece narsisim, genişletilmiş benlik ve tüketim yazınının bir araya getirilmesi ile hem araştırma sorunsalına ilişkin daha kapsayıcı bir açıklama elde edilmiş hem de söz konusu üç yazının desteklenmesine ve kimi açılardan geliştirme önerileri sunulmasına olanak sağlamıştır.

Araştırmanın sorunsalına ilişkin yukarıda ifade edilen sonuçların yanı sıra, araştırmada dikkat çekici başka hususlara da ulaşılmıştır. Araştırma kapsamında kişilerin çocukları hakkında konuşuyor görünmelerine rağmen aslında kendi benliklerini, mükemmelliklerini ve ne kadar iyi birer anne/eş olduklarını anlattıkları söylenebilir (McNeill ve Graham, 2014). Dahası, çocuklarının üstünlükleri vurgulanırken aslında "kendi çocukları" olmasından hareketle esasen kendi üstünlükleri ifade edilmektedir. Hatta birçok yerde bu durum açıkça da belirtilmiştir ("D gelinin kızı olmak kolay değil” gibi). Böylece kendi benliklerinin uzantısı olarak kabul edilen ve bu kapsamda Freud'un (1957) kuramına uygun olarak narsisizmin "yansitmalı özdeşim" çerçevesinde nesneleştirilen çocuk, söz konusu mükemmelliğin ve üstünlüğün bir gösterim alanını oluşturmaktadır. Burada, araştırma sorusu bakımından bir diğer önemli nokta, tüm bu süreç açısından tüketimin asli bir rolünün bulunmasıdır. Başka bir ifadeyle, çocuk tüketim için araçsallaştırılmakta, böylece narsisizm kavramına uygun olarak nesneleştirilmektedir ve bu durum tüketim vesilesiyle gerçekleştirilmektedir (McDonald, Wearing ve Ponting, 2008). Başka bir ifadeyle, tüketim sosyal medyada annelerin narsisist benliklerini çocukları yardımıyla genişletmelerine yardımcı olmaktadır. Burada ilginç olan nokta, söz konusu durumun henüz iki aylık bebek sahibi anne için bile geçerli olmasıdır. Böylece, Genişletilmiş Benlik Kuramının öngördüğü biçimiyle, annelerin kendi benliklerinin bir uzantısı olarak çocuğun ve tüketiminin kabul edilmesi desteklenmektedir (McNeill ve Graham, 2014).

Anneliğin idealliğine ilişkin "vefakar ve cefakar" bir annelik ifade edilmektedir. Söz konusu ifade ise, artık kendisi için tüketim faaliyetinde bulunmayıp, çocuk için tüketmesi ile açıklanmaktadır. Benzer bir durum başka annelere anneliğe ilişkin fikirlerin bir çeşit eğitim gibi verilmesinde gerçekleşmektedir. Bu konuda 
da yine anneliğe dair öneriler ile tüketime dair öneriler kesişir gibi görünmektedir. Başka bir ifadeyle, "ideal anne" olarak çocuğun tüketimi kendi tüketiminin önüne geçmekte ve diğer annelere tavsiyeler verildiğinde de söz konusu tavsiyeler tüketime ilişkin olmaktadır. Böylece yine ideal annelik ve tüketim kavramları çakışmaktadır.

Çalışmadaki bir diğer ilginç nokta, çocuğun gelişim sürecine dair belki her aşamanın tüketimle ilişkili olarak değerlendirilmesi ve bir gösteriye dönüştürülmesidir. Söz konusu aşamalar tüm anneler tarafından benimsenmekte ve bu aşamaya ilişkin "ritüeller" yine tüketimle ilişkili olarak gerçekleştirilmektedir. Bunlardan birkaçı, doğum günü, diş buğdayı, hastaneden çıkış, milli ve dini bayramlar, yılbaşı ve pasta patlatmacadır ${ }^{4}$. Söz konusu süreçlerin en azından bir kısmı profesyonel fotoğrafçılar tarafından fotoğraflanmaktadır. Bu anlamda bahsi geçen süreçlerin bir "gösteri" olarak kurgulandığını ifade etmek abartı olmayacaktır. İncelenen hesaplarda sadece olumlu şeyler değil kimi zaman çocuğun hastalığı gibi olumsuz durumlar da paylaşılmaktadır. Ancak söz konusu olumsuz durumlara ilişkin paylaşımlar da yine çocuğun şık bir biçimde giydirilmiş bir fotoğrafının altında yapılmaktadır.

Özetlemek gerekirse, çocuk her bir durumda özne olarak değil, annenin narsisizminin, gösterişçi tüketiminin, ideal annelik gösterisinin vb. nesnesi konumunda bulunmaktadır. Nesneleştirme, narsisizm açısından beklenen bir sonuçtur (Freud, 1957). Başka bir ifadeyle, her ne kadar paylaşımların tamamı çocuk üzerine olsa da, çocuk özne olarak görülmemektedir. Nesneleştirme sürecinin her biçiminde tüketim birincil rol oynamaktadır.

4 Pasta patlatmaca, bebeğin gösterişli bir şekilde giydirilerek önünde duran yaş pastayı parçalamasının profesyonel bir fotoğrafçı tarafından fotoğrafının çekilmesini ifade etmektedir.
Çalışma özgün yanlarının yanı sıra, birçok kısıtı da barındırmaktadır. Çalışmanın önemli kısıtlarından biri, narsisim kavramının ele alınış biçimiyle ilgilidir. Çalışma sadece "kişilik özelliği olarak narsisizm" kavramına dair sonuçlar önermektedir. Bunun yanında özellikle örneklem yapısına dair kimi teknik kısıtlar da bulunmaktadır. Çalışmada, maksimum çeşitlilik ilkesi gereğince örneklemde yer alan kişilerin belirlenmesinde meslek grupları, ekonomik durum, sahip olunan çocuk sayısı gibi faktörler açısından farklılaşma sağlanmaya çalışılmıştır. Ancak eğitim düzeyi, yaş gibi farklılıkların ele alınması ile gerçekleştirilecek başka çalışmaların konunun zenginliğini artıracağ düşünülmektedir. Dahası, mevcut çalışmada örneklemi anneler oluşturmaktadır. Oysa narsisizm kavramı ne kadınlığa ne de anneliğe özgüdür ve bu çerçevede babalar için tekrarlanacak çalışmalar özgün sonuçlar verecektir. Dahası, \#instadad (Instagram babalarının kısaltılmış hali) gibi kavramların yaygınlaşması da, erkekler açısında söz konusu ilişkilerin ele alınmasının önemini vurgulamaktadır. Son olarak, mevcut çalışmada Türkiyeli hesaplar ele alınmaktadır. Her ne kadar narsisizm kültürel değil dönemsel bir olgu olarak değerlendirilse de (Campbell ve Foster, 2007), narsisizmin farklı kültürlerde farklı davranış biçimleri ile görünür kılınabileceği düşünülmektedir. Bu nedenle başka kültürlerden sosyal medya hesaplarının incelenmesi farklı kimi zengin veriler sunabilecektir.

\section{Ek 1 - Görüşülen Kişilere Dair Bilgiler}

Görüşülen kişilerin anonimliğinin sağlanması için anneler büyük harflerle kız çocukları ise küçük harflerle gösterilmektedir. Harfler alfabetik sıraya göre verilmiş olup annelerin veya kızlarının isimleriyle harfler arasında bir benzerlik kurulmaya çalışılmamıştır. 


\begin{tabular}{|l|}
\hline A: 62 bin 500 takipçi. Başörtülü. Tek çocuk. \\
\hline B: 27 bin 800 takipçi. Öğretmen. İki çocuk. \\
\hline C: 20 bin 100 takipçi. Íki çocuk. \\
\hline D: 81 bin takipçi. Tarih öğretmeni. Ekonomik durumu yüksek. Tek çocuk. \\
\hline E: 58 bin 600 takipçi. Blog yazarı. Muhabir. Tek çocuk. Ekonomik durumu yüksek. Kocaeli. \\
\hline F: 93 bin 700 takipçi. Prematüre doğmuş ikiz annesi. Ekonomik durumu düşük. Çalışmıyor. \\
\hline G: 10 bin 400 takipçi. Balıkesirli. Müzik öğretmeni. Eşi siyahi, kızı melez. Tek çocuk. \\
\hline H: 101 bin takipçi. Fizyoterapist. Ekonomik durumu yüksek. Başörtülü. Tek çocuk. Balıkesir. \\
\hline I: 451 bin takipçi. Üç çocuk. Rize. \\
\hline J: 235 bin takipçi. İki çocuk. Kızı 21 Eylül 2017 doğumlu. \\
\hline K: 235 bin takipçi. Mimar. Yüksek Lisans eğitimi var. Tek çocuk. \\
\hline
\end{tabular}

\section{Kaynakça}

Ahuvia, A. C. (2005). Beyond the Extended self: Loved Objects and Consumers' Identity Narratives. Journal of Consumer Research, 32(1), 171-184.

Andersen, L. P., Sorensen, E. ve Kjaer, M. B. (2008). Not Too Conspicuous, Mother's Consumption of Baby Clothing. European Advances in Consumer Research, 8, 94-98.

Barnett, M. D., Powell, H. A. (2016). Self-esteem Mediates Narcissism and Aggression among Women, but not Men: A Comparison of Two Theoretical Models of Narcissism among College Students. Personality and Individual Differences, 89, 100-104.

Belk, R. W. (1988). Possessions and the Extended Self. Journal of Consumer Research, 15(2), 139-168.

Belk, R. W. (1989). Extended Self and Extending Paradigmatic Perspective. Journal of Consumer Research, 16(1), 129-132.

Belk, R. W. (1990). The Role of Possessions in Constructing and Maintaining a Sense of Past. M. E. Goldberg, G. Gorn, R. W. Pollay (Ed.), Advances in Consumer Research içinde (s. 669-676). Provo, UT: Association for Consumer Research.
Bergman, S. M., Fearrington, M. E., Davenport, S. W., Bergman, J. Z. (2011). Millennials, Narcissism, and Social Networking: What Narcissists Do on Social Networking Sites and Why. Personality and Individual Differences, 50(5), 706-711.

Braun, V., Clarke, V. (2006). Using Thematic Analysis in Psychology. Qualitative Research in Psychology, 3(2), 77-101.

Braun, V., Clarke, V. (2012). Thematic Analysis. Cooper, H., Camic, Paul M., Long, D., Panter, A., Rindskof, D., Sher, K. (Ed.). The APA Handbook of Research Methods in Psychology (volumes 1-3) içinde. Washington, DC: American Psychological Association.

Buss, D. M., Chiodo, L. M. (1991). Narcissistic Acts in Everyday Life. Journal of Personality, 59(2), 179215.

Campbell, W. K., Foster, J. D. (2007). The Narcissistic Self: Background, an Extended Agency Model, and Ongoing Controversies. C. Sedikides, S. J. Spencer (Ed.), The Self içinde (s. 115-138). New York: Taylor \& Francis Group Psychology Press. 
Cisek, S. Z., Sedikides, C., Hart, C. M., Godwin, H. J., Benson, V., Liversedge, S. P. (2014). Narcissism and Consumer Behavior: A Review and Preliminary Findings. Frontiers in Psychology, 5, 1-8.

Clarke, V., Braun, V. (2014). Thematic Analysis. A. C. Micholas (Ed.), Encyclopedia of Quality of Life and Well-Being Research içinde (s. 6626-6628). Dordrecht: Springer.

Gorn, R. W. Pollay (Ed.), Advances in Consumer Research içinde (s. 669-676). Provo, UT: Association for Consumer Research.

Crockatt, P. (2006). Freud's 'On Narcissism: An Introduction'. Journal of Child Psychotheraphy, 32(1), 4-20.

Dewall, C. N., Buffardi, L. E., Bonser, I., Campbell, W. K. (2011). Narcissism and Implicit Attention Seeking: Evidence from Linguistic Analyses of Social Networking and Online Presentation. Personality and Individual Differences, 51(1), 57-62.

Freud, S. (1957). On Narcissism: An Introduction, C. M. Baines (Çev.). Standard Ed. 14, 67-102.

Fromm, E. (1997). Sahip Olmak Ya Da Olmak, İstanbul: Arıtan Yayınevi.

Goulding, C., Shankar, A., Elliott, R. (2002). Working Weeks, Rave Weekends:Identity Fragmentation and the Emergence of New Communities. Consumption Markets \& Culture, 5, 261-284.

Göka, E., Yüksel, F. V. ve Göral, S. (2006). İnsan İlişkilerinde Yansımalı Özdeşim. Türk Psikiyatri Dergisi, 17(1), 46-54.

Grijalva, E., Newman, D. A., Tay, L., Donnellan, M. B., Harms, P. D., Robins, R. W., Yan, T. (2015). Gender Differences in Narcissism: A Meta-Analytic Review. Psychological bulletin, 141(2), 261-296.

Harnish, R. J., Bridges, K. R. (2015). Compulsive Buying: The Role of Irrational Beliefs, Materialism, and Narcissism. Journal of Rational-Emotive, CognitiveBehavior Therapy, 33(1), 1-16.
Holtzman, N. S., Strube, M. J. (2010). Narcissism and Attractiveness. Journal of Research in Personality, 44(1), 133-136.

Holtzman, N. S., Vazire, S., Mehl, M. R. (2010). Sounds like a Narcissist: Behavioral Manifestations of Narcissism in Everyday Life. Journal of Research in Personality, 44(4), 478-484.

Horvath, S., Morf, C. C. (2010). To be Grandiose or not to be Worthless: Different Routes to Self-Enhancement for Narcissism and Self-Esteem. Journal of Research in Personality, 44(5), 585-592.

Jonason, P. K., Lyons, M., Bethell, E. (2014). The Making of Darth Vader: Parent-Child Care and the Dark Triad. Personality and Individual Differences, 67, 30-34.

Kang, Y. J., Park, S. Y. (2016). The Perfection of the Narcissistic Self: A Qualitative Study on Luxury Consumption and Customer Equity. Journal of Business Research, 69(9), 3813-3819.

Kimura, J., Sakashita, M. (2011). Who Determines the Ideal Self?: A Comparative Analysis of Non-Verbal Communication. NA-Advances in Consumer Research, 38, 893-894.

Lambert, A., Desmond, J. (2013). Loyal Now, but not Forever! A Study of Narcissism and Male Consumer-Brand Relationships. Psychology, Marketing, 30(8), 690-706.

Lee, S. Y., Gregg, A. P., Park, S. H. (2013). The Person in the Purchase: Narcissistic Consumers Prefer Products that Positively Distinguish Them. Journal of Personality and Social Psychology, 105(2), 335.

Lee, S. Y., Park, S. H. (2011). Narcissists as Consumers: Using Scarce Products to Validate Excessively Positive Self-View. NA-Advances in Consumer Research, 38, 894-895.

Lewis, J. (2009). Redefining Qualitative Methods: Believability in the Fifth Moment. International Journal of Qualitative Methods, 8(2), 1-14. 
Madrigal, R. (2000). The Influence of Social Alliances with Sports Teams on Intentions to Purchase Corporate Sponsors' Products. Journal of Advertising, 29(4), 13-24.

Mcdonald, M., Wearing, S., Ponting, J. (2007). Narcissism and Neo-liberalism: Work, Leisure, and Alienation in an Era of Consumption. Loisir et Société/Society and Leisure, 30(2), 489-510.

Mcneill, L., Graham, T. (2014). Mother's Choice: An Exploration of Extended Self in Infant Clothing Consumption. Journal of Consumer Behaviour, 13(6), 403-410.

Merriam, S. B. (1995). What Can You Tell from an N of 1?: Issues of Validity and Reliability in Qualitative Research. PAACE Journal of Lifelong Learning, 4, 51-60.

Miles, M. B., Huberman, A. M. (1984). Qualitative Data Analysis: An Expanded Sourcebook, London: Sage Publications.

Mittal, B. (2006). I, Me, and Mine-How Products Become Consumers' Extended Selves. Journal of Consumer Behaviour, 5(6), 550-562.

Ong, E. Y., Ang, R. P., Ho, J. C., Lim, J. C., Goh, D. H., Lee, C. S., Chua, A. Y. (2011). Narcissism, Extraversion and Adolescents' Self-Presentation on Facebook. Personality and Individual Differences, 50(2), 180-185.

Phillips, B. J., Sego, T. (2011). The Role of Identity in Disposal: Lessons from Mothers' Disposal of Children's Possessions. Marketing Theory, 11(4), 435454.

Pincus, A. L., Lukowitsky, M. R. (2010). Pathological Narcissism and Narcissistic Personality Disorder. Annual Review of Clinical Psychology, 6, 421-446.

Prendergast, G., Wong, C. (2003). Parental Influence on the Purchase of Luxury Brands of Infant Apparel: an Exploratory Study in Hong Kong. Journal of Consumer Marketing, 20(2), 157-169.
Rose, P. (2007). Mediators of the Association between Narcissism and Compulsive Buying: The Roles of Materialism and Impulse Control. Psychology of Addictive Behaviors, 21(4), 576.

Sedikides, C., Gregg, A. P., Cisek, S., Hart, C. M. (2007). The I That Buys: Narcissists as Consumers. Journal of Consumer Psychology, 17(4), 254-257.

Shankar, A., Fitchett, J. A. (2002). Having, Being and Consumption. Journal of Marketing Management, 18, 501-516.

Sheldon, P., Bryant, K. (2016). Instagram: Motives for Its Use and Relationship to Narcissism and Contextual Age. Computers in Human Behavior, 58, 89-97.

Skues, J. L., Williams, B., Wise, L. (2012). The Effects of Personality Traits, Self-Esteem, Loneliness, and Narcissism on Facebook Use Among University Students. Computers in Human Behavior, 28(6), 2414-2419.

Stephens D. L, Hill R. P. (1996). The Loss of Animal Companions: Ahumanistic and Consumption Perspective. Society and Animals, 4(2), 189-210.

Timımı, S. (2010). The McDonaldization of Childhood: Children's Mental Health in Neo-liberal Market Cultures. Transcultural Psychiatry, 47(5), 686-706.

Vazire, S., Naumann, L. P., Rentfrow, P. J., Gosling, S. D. (2008). Portrait of a Narcissist: Manifestations of Narcissism in Physical Appearance. Journal of Research in Personality, 42(6), 1439-1447.

Velov, B., Gojković, V., Đurić, V. (2014). Materialism, Narcissism and the Attitude Towards Conspicuous Consumption. Psihologija, 47(1), 113-129.

Walsh, F. (2007). Traumatic Loss and Major Disasters: Strengthening Family and Community Resilience. Family Process, 46(2), 207-227. 